\title{
Clinical characteristics of women captured by extending the definition of severe postpartum haemorrhage with 'refractoriness to treatment': a cohort study
}

Dacia D. C. A. Henriquez ${ }^{1,2,3,4^{*}}$ D, Ada Gillissen ${ }^{1,2,3,4}$, Sharissa M. Smith ${ }^{1,2,3,4}$, Roos A. Cramer ${ }^{1,2,3,4}$, Thomas van den Akker ${ }^{1}$, Joost J. Zwart ${ }^{5}$, Jos J. M. van Roosmalen ${ }^{6}$, Kitty W. M. Bloemenkamp ${ }^{7}$, Johanna G. van der Bom ${ }^{2,3,4}$ and on behalf of the TeMpOH-1 study group

\begin{abstract}
Background: The absence of a uniform and clinically relevant definition of severe postpartum haemorrhage hampers comparative studies and optimization of clinical management. The concept of persistent postpartum haemorrhage, based on refractoriness to initial first-line treatment, was proposed as an alternative to common definitions that are either based on estimations of blood loss or transfused units of packed red blood cells (RBC). We compared characteristics and outcomes of women with severe postpartum haemorrhage captured by these three types of definitions.

Methods: In this large retrospective cohort study in 61 hospitals in the Netherlands we included 1391 consecutive women with postpartum haemorrhage who received either $\geq 4$ units of RBC or a multicomponent transfusion. Clinical characteristics and outcomes of women with severe postpartum haemorrhage defined as persistent postpartum haemorrhage were compared to definitions based on estimated blood loss or transfused units of RBC within $24 \mathrm{~h}$ following birth. Adverse maternal outcome was a composite of maternal mortality, hysterectomy, arterial embolisation and intensive care unit admission.

Results: One thousand two hundred sixty out of 1391 women (90.6\%) with postpartum haemorrhage fulfilled the definition of persistent postpartum haemorrhage. The majority, 820/1260 (65.1\%), fulfilled this definition within $1 \mathrm{~h}$ following birth, compared to 819/1391 (58.7\%) applying the definition of $\geq 1 \mathrm{~L}$ blood loss and 37/845 (4.4\%) applying the definition of $\geq 4$ units of RBC. The definition persistent postpartum haemorrhage captured $430 / 471$ adverse maternal outcomes (91.3\%), compared to $471 / 471$ (100\%) for $\geq 1$ L blood loss and 383/471 (81.3\%) for $\geq 4$ units of RBC. Persistent postpartum haemorrhage did not capture all adverse outcomes because of missing data on timing of initial, first-line treatment.
\end{abstract}

Conclusion: The definition persistent postpartum haemorrhage identified women with severe postpartum haemorrhage at an early stage of haemorrhage, unlike definitions based on blood transfusion. It also captured a large majority of adverse maternal outcomes, almost as large as the definition of $\geq 1 \mathrm{~L}$ blood loss, which is commonly applied as a definition of postpartum haemorrhage rather than severe haemorrhage.

Keywords: Definition, Maternal morbidity, Maternal mortality, Postpartum haemorrhage

\footnotetext{
* Correspondence: d.d.c.a.henriquez@lumc.nl

'Department of Obstetrics, Leiden University Medical Centre, Leiden, the

Netherlands

${ }^{2}$ Centre for Clinical Transfusion Research, Sanquin/LUMC, Leiden, the

Netherlands

Full list of author information is available at the end of the article
}

(c) The Author(s). 2019 Open Access This article is distributed under the terms of the Creative Commons Attribution 4.0 International License (http://creativecommons.org/licenses/by/4.0/), which permits unrestricted use, distribution, and reproduction in any medium, provided you give appropriate credit to the original author(s) and the source, provide a link to the Creative Commons license, and indicate if changes were made. The Creative Commons Public Domain Dedication waiver (http://creativecommons.org/publicdomain/zero/1.0/) applies to the data made available in this article, unless otherwise stated. 


\section{Background}

Postpartum haemorrhage is a common obstetric emergency, complicating $3-8 \%$ of all births [1-6]. Severe postpartum haemorrhage accounts for more than a quarter of all maternal deaths worldwide [7], and is the leading cause of severe maternal morbidity in highresource countries $[4,5,8-10]$. Consequently, prevention and optimization of its management continue to receive considerable attention.

Optimization of management of postpartum haemorrhage, however, is currently hampered by the use of many different definitions of severe postpartum haemorrhage. Commonly used definitions of postpartum haemorrhage and its severity are based on estimations of blood loss or the need of transfusion of packed red blood cells (RBC) within 24h following birth [11-19]. Severity of postpartum haemorrhage, however, depends not only on volume, but also on the rate of blood loss, physiological response to bleeding and response to treatment [11, 20, 21]. Such characteristics of bleeding are important determinants of clinical management during the dynamic process of ongoing haemorrhage [20]. The need for transfusion on the other hand, reflects an intermediary state during ongoing bleeding or the end stage of haemorrhage, and is therefore unsuitable when it comes to decisions regarding when to start more aggressive interventions to prevent adverse maternal outcome in women with severe postpartum haemorrhage.

Because of these shortcomings, a panel of experts on postpartum haemorrhage proposed to define severe postpartum haemorrhage not only according to the volume of blood loss, but also to failure to respond to initial, first-line measures to control bleeding. An important advantage of this definition, which they named persistent postpartum haemorrhage [11], is that it can be universally applied in low-, middle- and high-income settings, since the initial, first-line uterotonic and surgical measures to stop bleeding are commonly performed across all regions. This includes regions dealing with lack of blood for transfusion, where many women who suffer from severe haemorrhage would not be included if case definitions based on the number of transfusions given would be applied [17]. Furthermore, 'refractoriness to treatment' is a clear-cut moment during haemorrhage that may allow for differentiation between women who will stop bleeding soon, and those with ongoing haemorrhage who are at increased risk of adverse maternal outcome.

In order to gain knowledge on the case-mix of women captured by persistent postpartum haemorrhage as a definition of severe postpartum haemorrhage, we aimed to describe clinical characteristics and outcomes of women selected by this definition, as compared to definitions based on estimations of blood loss and transfused RBC.

\section{Methods}

\section{Population}

The current analysis was performed as part of the TeMpOH-1 study, a cohort study in the Netherlands on Transfusion strategies in women with Major Obstetric Haemorrhage in which 61 out of 86 hospitals (71\%) participated. In the TeMpOH-1 study, we included consecutive women who, from January 1st, 2011, to January 1st, 2013, received either $\geq 4$ units of $\mathrm{RBC}$ or a multicomponent blood transfusion within $24 \mathrm{~h}$ following birth because of postpartum haemorrhage exceeding $1000 \mathrm{~mL}$ of blood loss. A multicomponent blood transfusion was defined as blood transfusion consisting of a combination of RBC and fresh frozen plasma and/or platelet concentrates. Women were retrospectively selected from transfusion databases and birth registries of participating hospitals.

The study was registered in the Netherlands Trial Register (identifier NTR 4079).

\section{Data collection}

Detailed information concerning pregnancy, birth and the course of bleeding was gathered from routinely documented medical information. Comprehensive chart reviews were uniformly performed by well-trained medical students and research nurses. At the end of data collection, the first author and two data managers checked all data for completeness and inconsistencies, and whenever necessary, on-site chart review was repeated.

Collected data included age, ethnicity, weight, height, comorbidity, mode of birth, primary cause of haemorrhage, consecutive estimates of blood loss and timing of estimations, blood pressure and heart rate throughout the haemorrhage and timing of measurements, volume of clear fluids for fluid resuscitation and timing of administration, timing of all obstetric and haemostatic interventions to control bleeding, timing of administration of every unit of $\mathrm{RBC}$, fresh frozen plasma and platelets.

\section{Outcomes}

We followed women from onset of childbirth until cessation of bleeding postpartum or death, and in this manner reconstructed the course of every included woman with postpartum haemorrhage. Primary outcome was adverse maternal outcome, a composite of maternal mortality and severe maternal morbidity, with the latter defined as postpartum arterial embolisation, hysterectomy or intensive care unit admission. Secondary outcomes were total blood loss, time from birth until cessation of bleeding or death, total number of units of $\mathrm{RBC}$ transfused and time from birth till transfusion of first unit of RBC. 


\section{Persistent postpartum haemorrhage}

Persistent postpartum haemorrhage was defined as ongoing postpartum haemorrhage of at least $1000 \mathrm{~mL}$ within $24 \mathrm{~h}$ following birth, refractory to initial, first-line treatment to stop bleeding [11]. Initial, first-line treatment depended on the primary cause of postpartum haemorrhage. Postpartum haemorrhage caused by uterine atony, retained placenta, genital tract trauma, placenta previa or placental abruption was considered persistent if bleeding continued despite uterine massage, oxytocin, misoprostol, methylergometrine, suturing of tears, and manual removal of placenta or placental remnants. Women with abnormally invasive placenta as primary cause of postpartum haemorrhage, a surgical cause (including uterine rupture) or a pre-existent coagulation disorder (congenital or acquired) were regarded as having persistent postpartum haemorrhage irrespective of initial first-line treatment, since these complex haemorrhages require a series of obstetric and haemostatic measures to control bleeding.

\section{Blood loss, bleeding rate and signs of haemorrhagic shock at time of inclusion}

In the Netherlands, volume of blood loss during postpartum haemorrhage is determined by weighing gauzes, cloths and surgical swabs and by measurements using suction canisters. We linearly interpolated volume of blood loss between consecutive estimations of blood loss throughout bleeding, by using all recorded estimations of blood loss and timing of measurements from onset until cessation of bleeding. Cessation of bleeding was defined as the time of the last estimation of blood loss recorded in the medical files or the time of the last obstetric intervention to stop bleeding. Bleeding rate was calculated by dividing blood loss between two consecutive estimations by the time interval in between. At least one measurement of systolic blood pressure $\leq 90 \mathrm{mmHg}$ and/or a heart rate $\geq 120$ beats per minute from start of haemorrhage till time of inclusion were considered signs of haemorrhagic shock [22].

\section{Statistical analysis}

We summarized clinical characteristics and outcomes of women captured by the definition persistent postpartum haemorrhage and of women captured by different cut-offs for estimated blood loss and for transfused units of RBC within $24 \mathrm{~h}$ following birth. Cut-offs used for estimations of blood loss were: $\geq 1000 \mathrm{~mL}, \geq 1500 \mathrm{~mL}, \geq 2000 \mathrm{~mL}$ and $\geq$ $2500 \mathrm{~mL}$. Cut-offs for the number of transfused units of RBC were: $\geq 4$ units, $\geq 6$ units, $\geq 8$ units and $\geq 10$ units.

For every one of these nine definitions, we determined bleeding characteristics of all women who complied with the definition of interest. Bleeding characteristics were calculated at the time of satisfying the criteria for each of the definitions. For example, in case of estimation of volume of blood loss, we calculated all bleeding characteristics at the moment the women's blood loss reached the predefined cut-off value. Bleeding characteristics included time from birth to time of inclusion $(<1 \mathrm{~h}, \geq 1$ to $2 \mathrm{~h}, \geq 2 \mathrm{~h}$ ), cause of haemorrhage (uterine atony/retained placenta/abnormally invasive placenta/placenta previa/ placental abruption/surgical cause/pre-existent coagulation disorder), volume of blood loss at moment of inclusion $(<1 \mathrm{~L}, \geq 1$ to $2 \mathrm{~L}, \geq 2 \mathrm{~L}$ ), bleeding rate at moment of inclusion $(<1 \mathrm{~L} / \mathrm{h}, \geq 1$ to $2 \mathrm{~L} / \mathrm{h}, \geq 2 \mathrm{~L} / \mathrm{h})$, signs of haemorrhagic shock at moment of inclusion (no/yes), and units of transfused RBC at moment of satisfying the criteria for the definition (no/yes).

We also determined the occurrence of adverse maternal outcome for women captured by all definitions of severe postpartum haemorrhage. Lastly, we calculated for all definitions median blood loss, time from birth till end of bleeding, median number of transfused units of $\mathrm{RBC}$ and time from birth until transfusion of first unit of RBC.

\section{Results}

A total of 1391 women with postpartum haemorrhage out of 270,101 births met the TeMpOH-1 inclusion criteria (5.1 per 1000 births). Persistent postpartum haemorrhage was observed in 1260 women (90.6\%) (Fig. 1). A total of 1344 out of 1391 women (96.6\%) reached a minimal volume of blood loss of $1500 \mathrm{~mL}$ following birth, $1252(90.0 \%) \geq 2000$ $\mathrm{mL}$ and $1050(75.5 \%) \geq 2500 \mathrm{~mL}$ of blood loss within $24 \mathrm{~h}$ following birth (Fig. 1). At least 4 units of RBC were transfused within $24 \mathrm{~h}$ following birth in 845/1391 women (60.7\%), $\geq 6$ units in $325 / 1391$ women $(23.4 \%), \geq 8$ units in $176 / 1391$ women (12.7\%) and $\geq 10$ units in $115 / 1391$ women $(8.3 \%)$. Please note that women who received six or more units of $\mathrm{RBC}$ also met the criteria for inclusion in the previous category ( $\geq 4$ units of $\mathrm{RBC}$ ), and so on.

Time from birth to moment of meeting the criteria for persistent postpartum haemorrhage was less than $1 \mathrm{~h}$ in 820 out of 1260 women (65.1\%). At the moment of meeting these criteria, 673 women (53.4\%) had bled less than $1 \mathrm{~L}$ (Tables 1 and 2). When defining severe postpartum haemorrhage based on estimated blood loss, time from birth to the moment she reached $1 \mathrm{~L}$ of blood loss was less than $1 \mathrm{~h}$ in 819 out of 1391 women (58.7\%). With the number of transfused units of RBC within $24 \mathrm{~h}$ following birth as definition, time from birth to moment of transfusion of 4 units of RBC was less than $1 \mathrm{~h}$ in 37 out of 845 women (4.4\%).

Mode of birth for women meeting the criteria for persistent postpartum haemorrhage was vaginal in 967 out of 1260 women (76.7\%), comparable to women captured by all definitions based on estimated blood loss and transfusion of RBC up to a minimum of 4 units. A total of 62 out of 126 women (49.2\%) captured by the definition $\geq 10$ units of $R B C$ had a vaginal birth. Cause of 


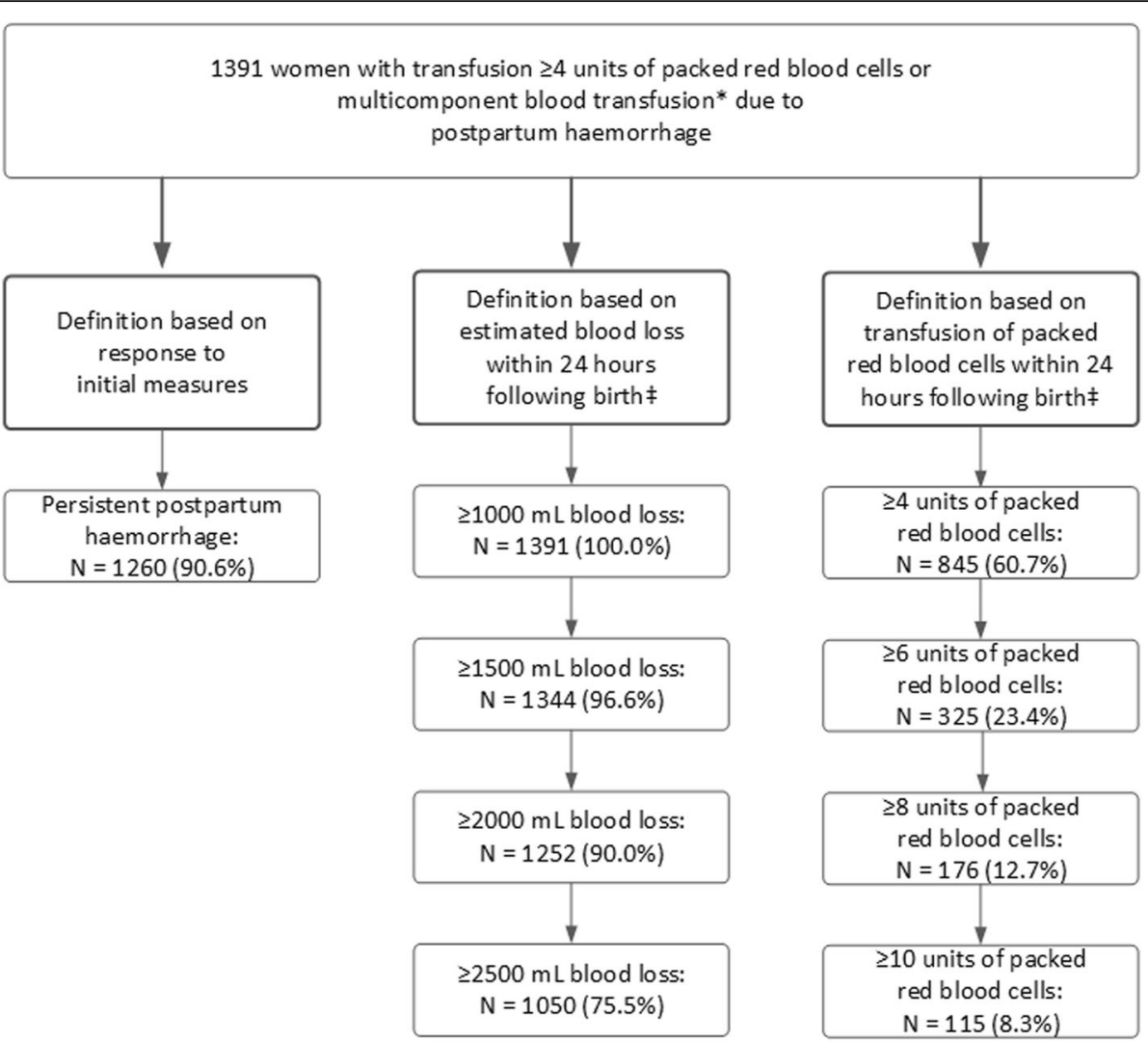

Fig. 1 Number of women meeting the criteria for persistent postpartum haemorrhage as definition of severe postpartum haemorrhage, and women captured by definitions of severe postpartum haemorrhage based on estimated blood loss and number of transfused units of packed red blood cells within $24 \mathrm{~h}$ following birth. * A multicomponent blood transfusion was defined as blood transfusion consisting of a combination of RBC and fresh frozen plasma and/or platelet concentrates. ¥ Women who bled $\geq 1500 \mathrm{ml}$ also fulfilled the definition $\geq 1000 \mathrm{ml}$ and were also included in this previous category, and so on. Similarly, women who received $\geq 6$ units of RBC also met the criteria for inclusion in the previous category ( $\geq 4$ units of $R B C$ ), etc

haemorrhage showed similar distributions for women categorized according to all definitions, with uterine atony as main cause of haemorrhage. With definitions based on the number of units transfused RBC within $24 \mathrm{~h}$ following birth the proportion of abnormally invasive placenta, surgical causes and congenital or acquired coagulation disorders increased slightly with increasing number of transfused units.

Adverse maternal outcome occurred in 471 out of 1391 women (33.9\%) in our study. In the 1260 women meeting the criteria for persistent postpartum haemorrhage we observed 430 of these 471 women with adverse outcome (91.3\%). The 41 women with adverse maternal outcome not captured by the definition persistent postpartum haemorrhage all had missing data on timing of initial firstline measures to stop bleeding, and therefore could not be classified as having had persistent postpartum haemorrhage or not. Because of this, nine women with hysterectomies and eight with arterial embolisations were 'missed' with this definition (Table 3).
The definition $\geq 1 \mathrm{~L}$ of blood loss within $24 \mathrm{~h}$ following birth captured all 471 adverse outcomes and in women with $\geq 2.5 \mathrm{~L}$ blood loss 417 of these 471 outcomes (88.5\%) were captured. One woman who was not captured by the latter definition died. She had postpartum haemorrhage with blood loss of $1.5 \mathrm{~L}$ due to uterine atony, but also suffered from cerebral haemorrhage as a result of eclampsia. Two women with hysterectomies ( $1 \mathrm{x}$ abnormally invasive placenta and $1 \mathrm{x}$ uterine atony) and five with embolisations ( $4 \mathrm{x}$ uterine atony and $1 \mathrm{x}$ surgical cause) were not captured by the definition of $\geq 2.5 \mathrm{~L}$ blood loss within $24 \mathrm{~h}$ following birth, partly because of uncertain total blood loss after postpartum haemorrhage.

A total of 383 out of 471 adverse outcomes (81.3\%) were captured by the definition transfusion of $\geq 4$ units of RBC within $24 \mathrm{~h}$ following birth and 113 out of 471 adverse outcomes $(24.0 \%)$ in women with $\geq 10$ units of RBC transfused. Among the 88 women with adverse outcome not captured by the definition $\geq 4$ units of RBC within $24 \mathrm{~h}$ following birth were five women with 
Table 1 Bleeding characteristics at time of inclusion of women with persistent postpartum haemorrhage, as compared with women with different cut-off values for estimations of blood loss within $24 \mathrm{~h}$ following birth. Women with higher volumes of blood loss are included in the cohorts starting with lower volumes of blood loss

\begin{tabular}{|c|c|c|c|c|c|}
\hline Bleeding characteristic & $\begin{array}{l}\text { Persistent postpartum } \\
\text { haemorrhage }(N=1260)\end{array}$ & $\begin{array}{l}\text { Blood loss } \geq 1000 \mathrm{~mL} \\
(N=1391)\end{array}$ & $\begin{array}{l}\text { Blood loss } \geq 1500 \mathrm{~mL} \\
(N=1344)\end{array}$ & $\begin{array}{l}\text { Blood loss } \geq 2000 \mathrm{~mL} \\
(N=1252)\end{array}$ & $\begin{array}{l}\text { Blood loss } \geq 2500 \mathrm{~mL} \\
(N=1050)\end{array}$ \\
\hline \multicolumn{6}{|c|}{ Time from birth till inclusion of patients - no. (\%) } \\
\hline$<1 \mathrm{~h}$ & $820(65.1)$ & $819(58.7)$ & $553(41.1)$ & $309(24.7)$ & $160(15.2)$ \\
\hline$\geq 1-2 h$ & $251(19.9)$ & $318(22.9)$ & $385(28.6)$ & $419(33.5)$ & $341(32.5)$ \\
\hline$\geq 2 \mathrm{~h}$ & $189(15.0)$ & $257(18.5)$ & $406(30.2)$ & $524(41.9)$ & $549(52.3)$ \\
\hline \multicolumn{6}{|l|}{ Mode of birth - no. (\%) } \\
\hline Vaginal & $967(76.7)$ & $1032(74.2)$ & $1002(74.6)$ & $945(75.5)$ & $792(75.4)$ \\
\hline Caesarean & $285(22.6)$ & $351(25.2)$ & $3354(24.9)$ & $301(24.0)$ & $253(24.1)$ \\
\hline Unknown & $8(0.6)$ & $8(0.6)$ & $7(0.5)$ & $6(0.5)$ & $5(0.5)$ \\
\hline \multicolumn{6}{|l|}{ Cause of haemorrhage - no. (\%) } \\
\hline Uterine atony & $805(63.9)$ & $901(64.8)$ & $874(65.0)$ & $824(65.8)$ & $685(65.2)$ \\
\hline Retained placenta & $219(17.4)$ & $231(16.6)$ & $227(16.9)$ & $207(16.5)$ & $172(16.4)$ \\
\hline Abnormally invasive placenta & $113(9.0)$ & $113(8.1)$ & $107(8.0)$ & $100(8.0)$ & $89(8.5)$ \\
\hline Placenta previa & $12(1.0)$ & $19(1.4)$ & $19(1.4)$ & $18(1.4)$ & $17(1.6)$ \\
\hline Placental abruption & $12(1.0)$ & $28(2.0)$ & $24(1.8)$ & $18(1.4)$ & $16(1.5)$ \\
\hline Surgical cause & $92(7.3)$ & $92(6.6)$ & $87(6.5)$ & $81(6.5)$ & $69(6.6)$ \\
\hline $\begin{array}{l}\text { Pre-existent coagulation } \\
\text { disorder }\end{array}$ & $7(0.6)$ & $7(0.5)$ & $6(0.4)$ & $4(0.3)$ & $2(0.2)$ \\
\hline \multicolumn{6}{|l|}{ Bleeding rate - no. (\%) } \\
\hline$<1 \mathrm{~L} / \mathrm{hr}$ & $457(36.3)$ & $496(35.7)$ & $508(37.8)$ & $499(39.9)$ & $432(41.1)$ \\
\hline$\geq 1-2 \mathrm{~L} / \mathrm{hr}$ & $316(25.1)$ & $332(23.9)$ & $315(23.4)$ & $302(24.1)$ & $266(25.3)$ \\
\hline$\geq 2 \mathrm{~L} / \mathrm{hr}$ & $481(38.2)$ & $552(39.7)$ & $513(38.2)$ & $445(35.5)$ & $349(33.2)$ \\
\hline Unknown & $6(0.5)$ & $11(0.8)$ & $8(0.6)$ & $6(0.5)$ & $3(0.3)$ \\
\hline \multicolumn{6}{|c|}{ Signs of haemorrhagic shock - no. (\%) } \\
\hline No & $344(27.3)$ & $416(29.9)$ & $385(28.6)$ & $295(23.6)$ & $190(18.1)$ \\
\hline Yes & $580(46.0)$ & $488(35.1)$ & $693(51.6)$ & $811(64.8)$ & $782(74.5)$ \\
\hline Unknown & $336(26.7)$ & $487(35.0)$ & $266(19.8)$ & $146(11.7)$ & $78(7.4)$ \\
\hline \multicolumn{6}{|c|}{ Packed red blood cells transfused - no. (\%) } \\
\hline No & $1196(94.9)$ & $1271(91.4)$ & $1145(85.2)$ & $888(70.9)$ & $536(51.0)$ \\
\hline Yes & $64(5.1)$ & $120(8.6)$ & 199 (14.8) & $364(29.1)$ & $514(49.0)$ \\
\hline
\end{tabular}

hysterectomies (4x abnormally invasive placenta and $1 \mathrm{x}$ placenta praevia) and 14 with arterial embolisations $(1 \mathrm{x}$ abnormally invasive placenta and $1 \mathrm{x}$ surgical cause).

Median total blood loss was $3.0 \mathrm{~L}$ (interquartile range, IQR 2.5-4.0) in women with persistent postpartum haemorrhage, similar to women with up to $2000 \mathrm{~mL}$ of blood loss at moment of inclusion (Table 4). Women with $\geq 2500 \mathrm{~mL}$ had median blood loss of $3.5 \mathrm{~L}$ (IQR 3.0-4.2). Number of transfused RBCs did not differ between definition persistent postpartum haemorrhage and all definitions based on estimated blood loss. With increasing units of RBC transfused median total blood loss increased from 3.4 L (IQR 2.5-4.5) to $7.0 \mathrm{~L}$ (IQR 5.3-9.1) and median units transfused increased from 5 (IQR 4-7) to 13 (IQR 11-17).

\section{Discussion}

\section{Main findings}

A large proportion of women who fulfilled the definition persistent postpartum haemorrhage was captured at an early stage of haemorrhage (within $1 \mathrm{~h}$ after birth), and this definition captured a high proportion of adverse maternal outcomes (91.3\%). Women with this definition for severe postpartum haemorrhage had similar clinical characteristics and maternal outcomes compared to women who fulfilled the definition of severe postpartum haemorrhage up to $2000 \mathrm{~mL}$ of blood loss.

\section{Strengths and limitations}

To the best of our knowledge, this is the first study in a large, consecutive cohort of women with postpartum 
Table 2 Bleeding characteristics at time of inclusion of women with persistent postpartum haemorrhage, as compared with women with different cut-off values for transfused units of packed red blood cells (RBC) within $24 \mathrm{~h}$ following birth. Women with higher numbers of RBCs are included in cohorts of women with fewer units transfused

\begin{tabular}{|c|c|c|c|c|c|}
\hline Bleeding characteristic & $\begin{array}{l}\text { Persistent postpartum } \\
\text { haemorrhage }(N=1260)\end{array}$ & $\begin{array}{l}\geq 4 \text { units } R B C \\
(N=845)\end{array}$ & $\begin{array}{l}\geq 6 \text { units } R B C \\
(N=325)\end{array}$ & $\begin{array}{l}\geq 8 \text { units } R B C \\
(N=176)\end{array}$ & $\begin{array}{l}\geq 10 \text { units } \mathrm{RBC} \\
(N=115)\end{array}$ \\
\hline \multicolumn{6}{|c|}{ Time from birth till inclusion of patients - no. (\%) } \\
\hline$<1 \mathrm{~h}$ & $820(65.1)$ & $37(4.4)$ & $9(2.8)$ & $4(2.3)$ & $2(1.7)$ \\
\hline$\geq 1-2 h$ & $251(19.9)$ & $96(11.4)$ & $41(12.6)$ & $11(6.3)$ & $3(2.6)$ \\
\hline$\geq 2 h$ & $189(15.0)$ & $712(84.3)$ & $275(84.6)$ & $161(91.5)$ & $110(95.7)$ \\
\hline Unknown & - & - & - & $1(0.5)$ & - \\
\hline \multicolumn{6}{|l|}{ Mode of birth - no. (\%) } \\
\hline Vaginal & $967(76.7)$ & $612(72.4)$ & $207(63.7)$ & $100(56.8)$ & $62(53.9)$ \\
\hline Caesarean & $285(22.6)$ & $228(27.0)$ & $116(35.7)$ & $75(42.6)$ & $53(46.1)$ \\
\hline Unknown & $8(0.6)$ & $5(0.6)$ & $2(0.6)$ & $1(0.6)$ & - \\
\hline \multicolumn{6}{|l|}{ Cause of haemorrhage - no. (\%) } \\
\hline Uterine atony & $805(63.9)$ & $539(63.8)$ & $214(65.8)$ & $107(60.8)$ & $66(57.4)$ \\
\hline Retained placenta & $219(17.4)$ & $135(16.0)$ & $29(8.9)$ & $18(10.2)$ & $13(11.3)$ \\
\hline Abnormally invasive placenta & $113(9.0)$ & $71(8.4)$ & $26(8.0)$ & $17(9.7)$ & $13(11.3)$ \\
\hline Placenta previa & $12(1.0)$ & $13(1.5)$ & $6(1.8)$ & $4(2.3)$ & $3(2.6)$ \\
\hline Placental abruption & $12(1.0)$ & $18(2.1)$ & $11(3.4)$ & $5(2.8)$ & $1(0.9)$ \\
\hline Surgical cause & $92(7.3)$ & $66(7.8)$ & $36(11.1)$ & $22(12.5)$ & $16(13.9)$ \\
\hline Pre-existent coagulation disorder & $7(0.6)$ & $3(0.4)$ & $3(0.9)$ & $3(1.7)$ & $3(2.6)$ \\
\hline \multicolumn{6}{|l|}{ Blood loss - no. (\%) } \\
\hline$<1 \mathrm{~L}$ & $673(53.4)$ & $7(0.8)$ & $1(0.3)$ & $1(0.6)$ & - \\
\hline$\geq 1-2 \mathrm{~L}$ & $407(32.3)$ & $82(9.7)$ & $15(4.6)$ & $3(1.7)$ & $2(1.7)$ \\
\hline$\geq 2 \mathrm{~L}$ & $180(14.3)$ & $756(89.5)$ & $309(95.1)$ & $172(97.7)$ & $113(98.3)$ \\
\hline \multicolumn{6}{|l|}{ Bleeding rate - no. (\%) } \\
\hline$<1 \mathrm{~L} / \mathrm{hr}$ & $457(36.3)$ & $689(81.5)$ & $24(74.2)$ & $127(72.2)$ & $80(69.6)$ \\
\hline$\geq 1-2 \mathrm{~L} / \mathrm{hr}$ & $316(25.1)$ & $100(11.8)$ & $56(17.2)$ & $34(19.3)$ & $21(18.3)$ \\
\hline$\geq 2 \mathrm{~L} / \mathrm{hr}$ & $481(38.2)$ & $41(4.9)$ & $23(7.1)$ & $12(6.8)$ & $12(10.4)$ \\
\hline Unknown & $6(0.5)$ & $15(1.8)$ & $5(1.5)$ & $3(1.7)$ & $2(1.7)$ \\
\hline \multicolumn{6}{|l|}{ Signs of haemorrhagic shock - no. (\%) } \\
\hline No & $344(27.3)$ & $85(10.1)$ & $23(7.1)$ & $9(5.1)$ & $6(5.2)$ \\
\hline Yes & $580(46.0)$ & $722(85.4)$ & $288(88.6)$ & $159(90.3)$ & $104(90.4)$ \\
\hline Unknown & $336(26.7)$ & $38(4.5)$ & $14(4.3)$ & $8(4.5)$ & $5(4.3)$ \\
\hline
\end{tabular}

haemorrhage that compared clinical characteristics and outcomes of women captured by different definitions of severe postpartum haemorrhage. Data were collected retrospectively, and we were able to reconstruct the course of every woman with postpartum haemorrhage without loss to follow-up. Previously, many authors discussed the use of different definitions, and experts proposed various new or adapted definitions of severe postpartum haemorrhage $[11,14,15,19,21,23,24]$. This study provides insight into variations in bleeding characteristics and maternal outcomes depending on the definition used.
However, our study population comprised only women with postpartum haemorrhage who received 4 or more units of $\mathrm{RBC}$ or a multicomponent blood transfusion within $24 \mathrm{~h}$ following birth, and our results cannot be generalized to all women who satisfy the criteria for persistent postpartum haemorrhage. The effects on clinical practice of extending the definition of severe postpartum haemorrhage with 'refractoriness to treatment' will need to be addressed in studies among all women meeting the criteria of persistent postpartum haemorrhage. In the updated version of the French guideline on postpartum haemorrhage, the definition persistent postpartum haemorrhage and 
Table 3 Adverse maternal outcome in women with persistent postpartum haemorrhage, compared with women with different cutoff values for estimations of blood loss and transfused packed red blood cells within $24 \mathrm{~h}$ following birth

\begin{tabular}{|c|c|c|c|c|c|}
\hline Definition based on & Maternal death & Hysterectomy & Arterial embolisation & $\begin{array}{l}\text { Admission on intensive } \\
\text { care unit }\end{array}$ & $\begin{array}{l}\text { Composite adverse } \\
\text { maternal outcome }\end{array}$ \\
\hline \multicolumn{6}{|l|}{ Number of patients (\%) } \\
\hline $\begin{array}{l}\text { Persistent postpartum haemorrhage } \\
(N=1260)\end{array}$ & $7(0.6)$ & $64(5.1)$ & $165(13.1)$ & $362(28.7)$ & $430(34.1)$ \\
\hline \multicolumn{6}{|l|}{ Estimated blood loss } \\
\hline$\geq 1000 \mathrm{~mL}(N=1391)$ & $7(0.5)$ & $73(5.2)$ & $173(12.4)$ & $399(28.7)$ & $471(33.9)$ \\
\hline$\geq 1500 \mathrm{~mL}(N=1344)$ & $7(0.5)$ & $73(5.4)$ & $171(12.7)$ & $388(28.9)$ & $459(34.2)$ \\
\hline$\geq 2000 \mathrm{~mL}(N=1252)$ & $6(0.5)$ & $73(5.8)$ & $171(13.7)$ & $372(29.7)$ & $443(35.4)$ \\
\hline$\geq 2500 \mathrm{~mL}(N=1050)$ & $6(0.6)$ & $71(6.8)$ & $168(16.0)$ & $348(33.1)$ & $417(39.7)$ \\
\hline \multicolumn{6}{|l|}{ Transfusion of packed red blood cells } \\
\hline$\geq 4$ units $(N=845)$ & $7(0.8)$ & $68(8.0)$ & $159(18.8)$ & $321(38.0)$ & $383(45.3)$ \\
\hline$\geq 6$ units $(N=325)$ & $5(1.5)$ & $62(19.1)$ & $125(38.5)$ & $215(66.2)$ & $258(79.4)$ \\
\hline$\geq 8$ units $(N=176)$ & $4(2.3)$ & $54(30.7)$ & $84(47.7)$ & $146(83.0)$ & $165(93.8)$ \\
\hline$\geq 10$ units $(N=115)$ & $3(2.6)$ & 44 (38.3) & $64(55.7)$ & $101(87.8)$ & $113(98.3)$ \\
\hline
\end{tabular}

failure of initial first-line management has been incorporated [25]. This guideline provides an opportunity to further analyse the consequences of implementing this definition in practice.

Another limitation are the 131 women (9.4\%) women in our cohort with missing information regarding the exact time at which the initial first-line measure to stop bleeding was employed. This excluded the possibility of classifying all women according to the criteria for persistent postpartum haemorrhage, and consequently, 41 women $(8.7 \%)$ with adverse maternal outcome had to be excluded. In daily clinical practice, these women would have been classified correctly by using this definition, as in daily clinical practice physicians will always have this information at their disposal.

\section{Interpretation}

One of the most striking findings of our study is that the use of the definition persistent postpartum haemorrhage seems to allow for early identification of women with severe bleeding and therefore early identification of women at risk of adverse maternal outcome. Recent studies on timing of interventions in women with postpartum haemorrhage have shown improvements in maternal outcome with early start of treatment [26, 27]. Early identification of women with high risk of adverse maternal outcome would facilitate this,

Table 4 Total blood loss and total units of transfused packed red blood cells in women with persistent postpartum haemorrhage, compared with women with different cut-off values for estimations of blood loss and transfused packed red blood cells (RBC) within $24 \mathrm{~h}$ following birth

\begin{tabular}{|c|c|c|c|c|}
\hline Definition based on & Total blood loss (L) & $\begin{array}{l}\text { Time from birth till end } \\
\text { of bleeding (hours) }\end{array}$ & $\begin{array}{l}\text { Total units of } \\
\text { transfused RBCs }\end{array}$ & $\begin{array}{l}\text { Time from birth till transfusion } \\
\text { of first RBC-unit (hours) }\end{array}$ \\
\hline \multicolumn{5}{|l|}{ Median (interquartile range) } \\
\hline Persistent postpartum haemorrhage $(N=1260)$ & $3.0(2.5-4.0)$ & $3.4(2.1-5.9)$ & $4(3-6)$ & $2.5(1.6-4.2)$ \\
\hline \multicolumn{5}{|l|}{ Estimated blood loss } \\
\hline$\geq 1000 \mathrm{~mL}(N=1391)$ & $3.0(2.5-4.0)$ & $3.3(2.0-5.8)$ & $4(3-6)$ & $2.5(1.5-4.2)$ \\
\hline$\geq 1500 \mathrm{~mL}(N=1344)$ & $3.0(2.5-4.0)$ & $3.3(2.0-5.8)$ & $4(3-6)$ & $2.5(1.5-4.2)$ \\
\hline$\geq 2000 \mathrm{~mL}(N=1252)$ & $3.0(2.5-4.0)$ & $3.4(2.1-5.9)$ & $4(3-6)$ & $2.4(1.5-4.1)$ \\
\hline$\geq 2500 \mathrm{~mL}(N=1050)$ & $3.5(3.0-4.2)$ & $3.6(2.1-6.1)$ & $4(3-6)$ & $2.3(1.5-3.8)$ \\
\hline \multicolumn{5}{|l|}{ Transfusion of packed red blood cells } \\
\hline$\geq 4$ units $(N=845)$ & $3.5(2.7-4.5)$ & $3.8(2.2-6.4)$ & $5(4-7)$ & $2.3(1.4-3.7)$ \\
\hline$\geq 6$ units $(N=325)$ & $4.8(3.6-6.5)$ & $6.5(3.1-8.6)$ & $8(6-12)$ & $2.0(1.0-3.3)$ \\
\hline$\geq 8$ units $(N=176)$ & $6.0(4.5-8.0)$ & $6.1(4.1-12.0)$ & $11(9-15)$ & $1.9(0.8-3.3)$ \\
\hline$\geq 10$ units $(N=115)$ & $7.0(5.1-9.8)$ & $6.9(4.4-12.8)$ & $13(11-18)$ & $1.8(0.7-3.0)$ \\
\hline
\end{tabular}


ultimately leading to a reduction in severe maternal morbidity and mortality. The fact that the definition persistent postpartum haemorrhage allows for earlier inclusion is an advantage over definitions based on estimated blood loss, since early inclusion would also allow for more robust prospective data collection during the course of haemorrhage.

The definition persistent postpartum haemorrhage captured more than 90\% women with adverse maternal outcome because of severe postpartum haemorrhage. This proportion was comparable to the proportions of the definitions based on estimated blood loss within $24 \mathrm{~h}$ following birth. Definitions based on transfusions of RBC yielded a selection of women with exceptionally high rates of adverse maternal outcome. However, the definition $\geq 4$ units of $\mathrm{RBC}$ within $24 \mathrm{~h}$ following birth excluded 88 women (18.7\%) with adverse maternal outcome, considerably higher than with the definition persistent postpartum haemorrhage and all definitions based on estimated blood loss. An explanation for this finding would be that a proportion of women with severe postpartum haemorrhage will undergo invasive procedures to stop bleeding before they may have reached four or more units of RBC transfused. This survival bias was previously also encountered in studies on massive transfusion in non-pregnant patients with major haemorrhage after trauma $[28,29]$. The fact that for all women with adverse outcomes missed by the definition, data essential for classification were absent from the medical records, underlines the requirement for adequate record keeping that the definition persistent postpartum haemorrhage needs. Implementing this definition may in this way contribute to improved documentation.

An observational study among pregnant and nonpregnant patients with massive transfusion because of major haemorrhage of different aetiologies also concluded that definitions of major haemorrhage based on massive transfusion are prone to exclude a substantial proportion of critically bleeding patients. The definition transfusion of $\geq 5$ units of RBC within a 4-h period excluded 77 out of 542 patients (14.2\%) with major haemorrhage [30].

The experts in a recent Delphi process led by the International Network of Obstetric Survey Systems needed seven rounds to reach consensus on a definition of severe postpartum haemorrhage, reaching a rate of agreement of 75\% [19]. This underlines the fact that it is rather challenging to accommodate the variety in opinion into one definition, and at the same time the need to explore new definitions or adaptations to existing definitions of severe postpartum haemorrhage $[11,14,15,20$, 21]. The definition persistent postpartum haemorrhage is internationally applicable and relies on basic interventions to control postpartum haemorrhage $[11,17]$. However, before its implementation as the standard to identify severe haemorrhage in clinical practice, audit, surveillance and research we will need to validate and test this definition also in other cohorts and different settings.

\section{Conclusion}

The definition persistent postpartum haemorrhage identified women with severe postpartum haemorrhage at an early stage of haemorrhage and captured a large proportion of adverse maternal outcomes. Clinical characteristics and outcomes of women included in this definition were comparable to those of women selected by definitions based on estimated blood loss up to $2 \mathrm{~L}$ within $24 \mathrm{~h}$ following birth, but not to definitions based on the number of units of RBC transfused. Whether or not extending the definition of severe postpartum haemorrhage with 'refractoriness to treatment' will lead to early identification of women at high risk of adverse outcome, early start of treatment and improvement of outcomes needs to be clarified in future studies.

\section{Supplementary information}

Supplementary information accompanies this paper at https://doi.org/10. 1186/s12884-019-2499-9.

Additional file 1. TeMpOH-1 study: participating hospitals.

\section{Abbreviation}

RBC: Packed red blood cells

\section{Acknowledgements}

We would like to thank all 61 participating hospitals and the Dutch Consortium for Healthcare Evaluation and Research in Obstetrics and Gynaecology - NVOG Consortium 2.0, medical students R.M. Loeff, R.J. van Goeverden, B. Eijlers, A. Hillebrand, S.E. Spelmink, T.J. Beunder, V. Harskamp, M. Wind, M.D. Koning, R.A. Cramer, A. Veenstra, S.M. Smith and E.E. Ensing, data managers C.J. van Brussel-de Groot, O. Zouitni and C. Caram-Deelder, research nurses C. Kolster-Bijdevaate, M.S. Bourgonje-Verhart, C.E. Bleeker-Taborh and E. Roos-van Milligen for their contributions to the TeMpOH-1 study.

TeMpOH-1 study group.

H.J. Adriaanse (MSc, PhD), Gelre Hospital, Medical Laboratory Head; E.S.A. van den Akker (MD, PhD), Onze Lieve Vrouwe Hospital, Obstetrician; M.I. Baas (MD, PhD), Hospital Rivierenland Tiel, Obstetrician; C.M.C. Bank (MSc),

Admiraal de Ruyter Hospital, Medical Laboratory Head; E. van Beek (MD, PhD), St. Antonius Hospital, Obstetrician; B.A. de Boer (MSc, PhD), Atalmedial, Medical Laboratory Head; K. de Boer (MD, PhD), Rijnstate Hospital, Obstetrician; D.M.R. van der Borden (MD, PhD), Regional Hospital Koningin Beatrix, Obstetrician; H.A. Bremer (MD, PhD), Reinier de Graaf Hospital, Obstetrician; J.T.J. Brons (MD, PhD), Medical Centre Twente, Obstetrician; J.M. Burggraaff (MD, PhD), Scheper Hospital, Obstetrician; H. Ceelie (MSc, PhD), Vlietland Hospital, Medical Laboratory Head; H. Chon (MSc, PhD), Tergooi Hospital, Medical Laboratory Heads; J.L.M. Cikot (MD, PhD), Van Weel-Bethesda Hospital, Obstetrician; F.M.C. Delemarre (MD, PhD), Elkerliek Hospital, Obstetrician; J.H.C. Diris (MSc, PhD), Bernhoven Hospital, Medical Laboratory Head; M. Doesburg-van Kleffens (MSc, PhD), Maas Hospital Pantein, Medical Laboratory Head; I.M.A. van Dooren (MD, PhD), St. Jans Hospital, Obstetrician; J.L.P. van Duijnhoven (MSc, PhD), Elkerliek Hospital, Medical Laboratory Head; F.M. van Dunné (MD PhD), Medical Centre Haaglanden, Obstetrician; J.J. Duvekot (MD, PhD), Erasmus Medical Centre, Obstetrician; P. Engbers (MSc, PhD), Bethesda Hospital, Medical Laboratory Head; M.J.W. van Etten-van Hulst (MD, PhD), Franciscus Hospital, Obstetrician; H. Feitsma (MD, PhD), Haga Hospital, Obstetrician; M.A. Fouraux (MSc, PhD), Ikazia Hospital, Medical Laboratory Head; M.T.M. Franssen (MD, PhD), University Medical Centre Groningen, Obstetrician; M.A.M. Frasa (MSc, PhD), Groene Hart Hospital, Medical Laboratory Head; A.J. van Gammeren (MSC, PhD), Amphia Hospital, Medical Laboratory Head; N. van Gemund (MD, PhD), Sint Franciscus Hospital, Obstetrician; F. van der Graaf (MSc, PhD), Máxima Medical 
Centre, Medical Laboratory Head; Prof. C.J.M. de Groot (MD, PhD), VU Medical Centre, Obstetrician; C.M. Hackeng (MSc, PhD), St. Antonius Hospital, Medical Laboratory Head; D.P. van der Ham (MD, PhD), Martini Hospital, Obstetrician; MJ.C.P. Hanssen (MD, PhD), Bethesda Hospital, Obstetrician; T.H.M. Hasaart (MD, PhD), Catharina Hospital, Obstetrician; H.A. Hendriks (MSc) Sint Lucas Andreas Hospital, Medical Laboratory Head; Y.M.C. Henskens (MSC, PhD), Maastricht University Medical Centre, Medical Laboratory Head; B.B.J. Hermsen (MD, PhD), Sint Lucas Andreas Hospital, Obstetrician; S. Hogenboom (MSc, PhD), Flevo Hospital, Medical Laboratory Head; A. Hooker (MD, PhD), Zaans Medical Centre, Obstetrician; F. Hudig (MSc, PhD), Haga Hospital, Medical Laboratory Head; A.M.G. Huijssoon (MD, PhD), Vlietland Hospital, Obstetrician; A.J.M. Huisjes (MD, PhD), Gelre Hospital, Obstetrician; N. Jonker (MSc, PhD), Wilhelmina Hospital, Medical Laboratory Head; P.J. Kabel (MSc, PhD), St. Elisabeth Hospital, Medical Laboratory Head; C. van Kampen (MSc, PhD), Gelderse Vallei Hospital, Medical Laboratory Head; M.H. de Keijzer (MSc, PhD), Rivierenland Tiel Hospital, Medical Laboratory Head; D.H. van de Kerkhof (MSc, PhD), Catharina Hospital, Medical Laboratory Head; J.F.W. Keuren (MSc, PhD), Zuwe Hofpoort Hospital, Medical Laboratory Head; J.F.W. Keuren (MSc, PhD), Groene Hart Hospital, Medical Laboratory Head; G. Kleiverda (MD, PhD), Flevo Hospital, Obstetrician; J.H. Klinkspoor (MSc, PhD), Amsterdam Medical Centre, Medical Laboratory Head; S.G.A. Koehorst (MSc, PhD), Slingeland Hospital, Medical Laboratory Head; M. Kok (MD, PhD), Amsterdam Medical Centre, Obstetrician; R.D. Kok (MD, PhD), Bernhoven Hospital, Obstetrician; J.B. de Kok (MSc, PhD), Deventer Hospital, Medical Laboratory Head; A. Koops (MD, PhD), Wilhelmina Hospital, Obstetrician; W. Kortlandt (MSc, PhD), Diakonessen Hospital, Medical Laboratory Head; J. Langenveld (MD, PhD), Atrium Medical Centre, Obstetrician; M.P.G. Leers (MSc, PhD), Atrium Medical Centre, Medical Laboratory Head; A. Leyte (MSc, PhD), Onze Lieve Vrouwe Gasthuis, Medical Laboratory Head; A. de Mare (MSc, PhD), Medlon, Medical Laboratory Head; G.D.M. Martens (MD, PhD), Zuwe Hofpoort Hospital, Obstetrician; J.H. Meekers, University Medical Centre Groningen, Employee laboratory; C.A. van Meir (MD, PhD), Groene Hart Hospital, Obstetrician; G.C.H Metz (MD, PhD), Ikazia Hospital, Obstetrician; E.C.H.J. Michielse (MSc, PhD), St. Jans Hospital, Medical Laboratory Head; L.J. Mostert (MSc, PhD), Van Weel-Bethesda Hospital, Medical Laboratory Head; S.W.H. Nij Bijvank (MD, PhD), Isala clinics, Obstetrician; E. Oostenveld (MD, PhD), Tjongerschans Hospital, Obstetrician; N. Osmanovic (MSc, PhD), Zaans Medical Centre, Medical Laboratory Head; M.A. Oudijk (MD, PhD), University Medical Centre Utrecht, Obstetrician; C. Pagano Mirani-Oostdijk (MSc, PhD), Franciscus Hospital, Medical Laboratory Head; E.C.M. van Pampus (MSc, PhD), University Medical Centre St. Radboud, Medical Laboratory Head; D.N.M. Papatsonis (MD, PhD), Amphia Hospital, Obstetrician; R.H.M. Peters (MD), Tjongerschans Hospital, Medical Laboratory Head; G.A.E. Ponjee (MSc, PhD), Medical Centre Haaglanden, Medical Laboratory Head; M. Pontesilli (MD, PhD student), Medical Centre Alkmaar, Fertility doctor; M.M. Porath (MD, PhD), Máxima Medical Centre, Obstetrician; M.S. Post (MD, PhD), Medical Centre Leeuwarden, Obstetrician; J.G.J. Pouwels (MSc, PhD), Scheper Hospital, Medical Laboratory Head; L. Prinzen (MSc, PhD), Sint Franciscus Hospital, Medical Laboratory Head; J.M.T. Roelofsen (MD, PhD), Lange Land Hospital, Obstetrician; J.J.M. Rondeel (MSc, PhD), Isala clinics, Medical Laboratory Head; P.C.M. van der Salm (MD, PhD), Meander Medical Centre, Obstetrician; H.C.J. Scheepers (MD, PhD), Maastricht University Medical Centre, Obstetrician; D.H. Schippers (MD, PhD), Canisius-Wilhelmina Hospital, Obstetrician; N.W.E. Schuitemaker (MD, PhD), Diakonessen Hospital, Obstetrician; J.M. Sikkema (MD, PhD), Hospital group Twente, Obstetrician; J. Slomp (MSc, PhD), Medical Spectre Twente, Medical Laboratory Head; J.W. Smit (MSc, PhD), Martini Hospital, Medical Laboratory Head; Y.S. Snuif-de Lange (MD, PhD), Admiraal de Ruyter Hospital, Obstetrician; J.W.J. van der Stappen (MSc, PhD), Canisius-Wilhelmina Hospital, Medical Laboratory Head; P. Steures (MD, PhD), St. Elisabeth Hospital, Obstetrician; G.H.M. Tax (MD, PhD), Reinier de Graaf Hospital, Medical Laboratory Head; M. Treskes (MSc, PhD), Tergooi
Hospital, Medical Laboratory Heads; H.J.L.M. Ulenkate (MSc, PhD), Zorgsaam Zeeuws-Vlaanderen Hospital, Medical Laboratory Head; G.A. van Unnik (MD, PhD), Diaconessen Hospital, Obstetrician; B.S. van der Veen (MSc, PhD), Medical Centre Leeuwarden, Medical Laboratory Head; T.E.M. Verhagen (MD, PhD), Slingeland Hospital, Obstetrician; J. Versendaal (MD), Maasstad Hospital, Obstetrician; B. Visschers (MD, PhD), Zorgsaam ZeeuwsVlaanderen Hospital, Obstetrician; O. Visser (MD, PhD), VU Medical Centre, Hematologist; H. Visser (MD, PhD), Tergooi Hospital Obstetrician; K.M.K. de Vooght (MSc, PhD), University Medical Centre Utrecht, Medical Laboratory Head; M.J. de Vries (MD, PhD), Rijnland Hospital, Obstetrician; H. de Waard (MSc, PhD), Rijnstate Hospital, Medical Laboratory Head; F. Weerkamp (MSc, PhD), Maasstad Hospital, Medical Laboratory Head; M.J.N. Weinans (MD, PhD), Gelderse Vallei Hospital, Obstetrician; H. de Wet (MD, PhD), Refaja Hospital Stadskanaal, Obstetrician; M. van Wijnen (MSc, PhD), Meander Medical Centre, Medical Laboratory Head; W.J. van Wijngaarden (MD, PhD), Bronovo Hospital, Obstetrician; A.C. de Wit (MD, PhD), Maas Hospital Pantein, Obstetrician; M.D. Woiski (MD, PhD), University Medical Centre St. Radboud, Obstetrician.

Sanquin Research is the scientific collaboration between the Department of Clinical Transfusion Research Sanquin Research, and the Department of Transfusion Medicine, Sanquin Blood Bank.

\section{Authors' contributions}

$\mathrm{DH}, \mathrm{KB}, \mathrm{JZ}, \mathrm{JR}$ and JB were responsible for study concept and design. DH monitored data collection for the whole trial, wrote the statistical analysis plan, cleaned and analysed the data. SS and RC collected data. DH and JB drafted and revised the paper. AG, KB, TA, JZ and JR critically reviewed the manuscript and approved the final version. All authors had full access to all of the data in the study and can take responsibility for the integrity of the data and the accuracy of the data analysis. All authors read and approved the final manuscript.

\section{Funding}

None.

\section{Availability of data and materials}

The datasets used and/or analysed during the current study are available from the corresponding author on reasonable request.

\section{Ethics approval and consent to participate}

The study was approved by the medical research ethics committee of the Leiden University Medical Center (P12.273). A waiver for informed consent from the individual patients was granted by this medical research ethics committee. Each participating hospital (Additional file 1) provided permission to conduct the study, ethics approval was not required from each hospital. All data were anonymized before being received by the research team. The study was registered in the Netherlands Trial Register (NTR4079).

\section{Consent for publication}

Not applicable.

\section{Competing interests}

TA and JR are on the editorial board of BMC Pregnancy and Childbirth. All other authors declare that they have no competing interests.

\section{Author details}

'Department of Obstetrics, Leiden University Medical Centre, Leiden, the Netherlands. ${ }^{2}$ Centre for Clinical Transfusion Research, Sanquin/LUMC, Leiden, the Netherlands. ${ }^{3}$ Jon J van Rood Centre for Clinical Transfusion Science, Leiden University Medical Center, Leiden, the Netherlands. ${ }^{4}$ Department of Clinical Epidemiology, Leiden University Medical Centre, Leiden, the Netherlands. ${ }^{5}$ Department of Obstetrics and Gynaecology, Deventer Hospital, Deventer, the Netherlands. ${ }^{6}$ Athena Institute, VU University, Amsterdam, the Netherlands. ${ }^{7}$ Department of Obstetrics, Birth Center Wilhelmina's Children Hospital, Division Woman and Baby, University Medical Center Utrecht, Utrecht, the Netherlands. 
Received: 5 October 2018 Accepted: 10 September 2019

Published online: 17 October 2019

\section{References}

1. Callaghan WM, Kuklina EV, Berg CJ. Trends in postpartum hemorrhage: United States, 1994-2006. Am J Obstet Gynecol. 2010;202(4):353.e351-6.

2. Ford JB, Patterson JA, Seeho SK, Roberts CL. Trends and outcomes of postpartum haemorrhage, 2003-2011. BMC Pregnancy Childbirth. 2015;15:334

3. Knight M, Callaghan WM, Berg C, Alexander S, Bouvier-Colle MH, Ford JB, Joseph KS, Lewis G, Liston RM, Roberts CL, et al. Trends in postpartum hemorrhage in high resource countries: a review and recommendations from the international postpartum hemorrhage collaborative group. BMC Pregnancy Childbirth. 2009:9:55

4. Mehrabadi A, Liu S, Bartholomew S, Hutcheon JA, Kramer MS, Liston RM, Joseph KS. Temporal trends in postpartum hemorrhage and severe postpartum hemorrhage in Canada from 2003 to 2010. J Obstet Gynaecol Can. 2014;36(1):21-33.

5. Roberts CL, Ford JB, Algert CS, Bell JC, Simpson JM, Morris JM. Trends in adverse maternal outcomes during childbirth: a population-based study of severe maternal morbidity. BMC Pregnancy Childbirth. 2009:9:7.

6. van Stralen G, von Schmidt Auf Altenstadt JF, Bloemenkamp KW, van Roosmalen J, Hukkelhoven CW. Increasing incidence of postpartum hemorrhage: the Dutch piece of the puzzle. Acta Obstet Gynecol Scand. 2016;95(10):1104-10

7. Say L, Chou D, Gemmill A, Tuncalp O, Moller AB, Daniels J, Gulmezoglu AM, Temmerman M, Alkema L. Global causes of maternal death: a WHO systematic analysis. Lancet Glob Health. 2014;2(6):e323-33.

8. Zwart JJ, Dupuis JR, Richters A, Ory F, van Roosmalen J. Obstetric intensive care unit admission: a 2-year nationwide population-based cohort study. Intensive Care Med. 2010;36(2):256-63.

9. Al-Zirqi I, Vangen S, Forsen L, Stray-Pedersen B. Prevalence and risk factors of severe obstetric haemorrhage. BJOG. 2008;115(10):1265-72.

10. Joseph KS, Rouleau J, Kramer MS, Young DC, Liston RM, Baskett TF. Investigation of an increase in postpartum haemorrhage in Canada. BJOG. 2007;114(6):751-9.

11. Abdul-Kadir R, McLintock C, Ducloy AS, El-Refaey H, England A, Federici AB, Grotegut CA, Halimeh S, Herman JH, Hofer S, et al. Evaluation and management of postpartum hemorrhage: consensus from an international expert panel. Transfusion. 2014;54(7):1756-68.

12. ACOG. Practice Bulletin No. 183: Postpartum Hemorrhage. Obstet Gynecol. 2017:130(4):e168-86

13. Brace V, Penney G, Hall M. Quantifying severe maternal morbidity: a Scottish population study. BJOG. 2004;111(5):481-4.

14. Kerr RS, Weeks AD. Postpartum haemorrhage: a single definition is no longer enough. BJOG. 2017;124(5):723-6.

15. Rath WH. Postpartum hemorrhage--update on problems of definitions and diagnosis. Acta Obstet Gynecol Scand. 2011;90(5):421-8.

16. Postpartum haemorrhage, prevention and management (Green-top guideline no. 52) [https://www.rcog.org.uk/en/guidelines-research-services/ guidelines/gtg52/I. Accessed 1 Sept 2018.

17. $\mathrm{WHO}$ recommendations for the prevention and treatment of postpartum haemorrhage. [http://apps.who.int/iris/bitstream/10665/75411/1/978924154 8502_eng.pdf]. Accessed 1 Sept 2018.

18. Zwart JJ, Richters JM, Ory F, de Vries Jl, Bloemenkamp KW, van Roosmalen J. Severe maternal morbidity during pregnancy, delivery and puerperium in the Netherlands: a nationwide population-based study of 371,000 pregnancies. BJOG. 2008;115(7):842-50.

19. Schaap T, Bloemenkamp K, Deneux-Tharaux C, Knight M, Langhoff-Roos J, Sullivan E, van den Akker T. Defining definitions: a Delphi study to develop a core outcome set for conditions of severe maternal morbidity. BJOG. 2019; 126(3):394-401. https://doi.org/10.1111/1471-0528.14833. Epub 2017 Aug 24.

20. Hancock A, Weeks AD, Lavender DT. Is accurate and reliable blood loss estimation the 'crucial step' in early detection of postpartum haemorrhage: an integrative review of the literature. BMC Pregnancy Childbirth. 2015;15:230.

21. Borovac-Pinheiro A, Pacagnella RC, Cecatti JG, Miller S, El Ayadi AM, Souza JP, Durocher J, Blumenthal PD, Winikoff B. Postpartum hemorrhage: new insights for definition and diagnosis. Am J Obstet Gynecol. 2018;219:162-8.

22. Evaluating the quality of care for severe pregnancy complications. The WHO near-miss approach for maternal health. [Available at: http://www. who.int/reproductivehealth/publications/monitoring/9789241502221/en/]. Accessed 1 Sept 2018.
23. McLintock $\mathrm{C}$, James $\mathrm{AH}$. Obstetric hemorrhage. J Thromb Haemost. 2011;9(8):1441-51

24. Zwart JJ, Yazdani ST, Harvey MS, de Vries RR, van Roosmalen J. Underreporting of major obstetric haemorrhage in the Netherlands. Transfus Med (Oxford, England). 2010;20(2):118-22.

25. Sentilhes L, Vayssiere C, Deneux-Tharaux C, Aya AG, Bayoumeu F, Bonnet MP, Djoudi R, Dolley P, Dreyfus M, Ducroux-Schouwey C, et al. Postpartum hemorrhage: guidelines for clinical practice from the French College of Gynaecologists and Obstetricians (CNGOF): in collaboration with the French Society of Anesthesiology and Intensive Care (SFAR). Eur J Obstet Gynecol Reprod Biol. 2016:198:12-21.

26. WOMAN_Trial_Collaborators. Effect of early tranexamic acid administration on mortality, hysterectomy, and other morbidities in women with postpartum haemorrhage (WOMAN): an international, randomised, double-blind, placebo-controlled trial. Lancet (London, England). 2017;389(10084):2105-16.

27. Howard TF, Grobman WA. The relationship between timing of postpartum hemorrhage interventions and adverse outcomes. Am J Obstet Gynecol. 2015;213(2):239.e231-3.

28. Ho AM, Dion PW, Yeung JH, Holcomb JB, Critchley LA, Ng CS, Karmakar MK, Cheung CW, Rainer TH. Prevalence of survivor bias in observational studies on fresh frozen plasma:erythrocyte ratios in trauma requiring massive transfusion. Anesthesiology. 2012;116(3):716-28.

29. Snyder CW, Weinberg JA, McGwin G Jr, Melton SM, George RL, Reiff DA Cross JM, Hubbard-Brown J, Rue LW 3rd, Kerby JD. The relationship of blood product ratio to mortality: survival benefit or survival bias? J Trauma. 2009:66(2):358-62 discussion 362-354

30. Zatta AJ, McQuilten ZK, Mitra B, Roxby DJ, Sinha R, Whitehead S, Dunkley S, Kelleher S, Hurn C, Cameron PA, et al. Elucidating the clinical characteristics of patients captured using different definitions of massive transfusion. Vox Sang. 2014;107(1):60-70.

\section{Publisher's Note}

Springer Nature remains neutral with regard to jurisdictional claims in published maps and institutional affiliations.

Ready to submit your research? Choose BMC and benefit from:

- fast, convenient online submission

- thorough peer review by experienced researchers in your field

- rapid publication on acceptance

- support for research data, including large and complex data types

- gold Open Access which fosters wider collaboration and increased citations

- maximum visibility for your research: over $100 \mathrm{M}$ website views per year

At BMC, research is always in progress.

Learn more biomedcentral.com/submissions 